\title{
Analysis of Factors for the Implementation of Accreditation Policy on Work Productivity in Ranomeeto Health Center South Konawe Regency
}

\author{
Armiati $^{1 *}$, Indar $^{1}$, Arifin Seweng ${ }^{2}$, Darmawansyah $^{1}$, Sukri Palutturi $^{1}$, Andi Zulkifli ${ }^{3}$ \\ ${ }^{1}$ Department of Health Administration and Policy, Faculty of Public Health, Hasanuddin University, Indonesia \\ ${ }^{2}$ Department of Biostatistics/KKB, Faculty of Public Health, Hasanuddin University, Indonesia \\ ${ }^{3}$ Department of Epidemiology, Faculty of Public Health, Hasanuddin University, Indonesia
}

\section{*Corresponding Author}

Armiati

\author{
Article History \\ Received: 25.06 .2020 \\ Accepted: 03.07.2020 \\ Published: 09.07.2020
}

\begin{abstract}
In order for the Community Health Center to perform its functions optimally, it is necessary to have a good management of the Community Health Center organization which includes service performance, service processes, and resources used. This study aims to determine the implementation of the accreditation policy on the work productivity of the Community Health Center in the South Konawe Regency. This type of descriptive qualitative research with exploratory methods. The informants of this study were 12 informants at the Ranomeeto Community Health Center. To find out the implementation of the Community Health Center accreditation policy. Data analysis with an interactive model consists of three stages of data reduction, data presentation, drawing conclusions. The results showed that the policy had been socialized at the level of health services in the South Konawe Regency to the respective Community Health Centers, the capacity of resources in terms of quantity was considered sufficient according to their competence in several Community Health Centers, limited health facilities and standardized health facilities. is still minimal, the communication element is that the Public Health Center staff in South Konawe Regency have participated in and held socialization related to accreditation policies, Public Health Center officials are also active in sharing knowledge so that it is expected that the implementation of the accreditation policy as an effort to encourage the performance of Community Health Center officials to be good and directed. It was concluded that the implementation of the accreditation policy could spur productivity in the performance of the Public Health Center staff. It is expected that the Ranomeeto Community Health Center can maintain what has been achieved during the accreditation process, and carry out regular work productivity measurements.
\end{abstract}

Keywords: Policy, accreditation standards, Productivity, Performance, Community Health Centers.

\section{INTRODUCTION}

The Community Health Center is one of the health facilities that provide first level health services that have an important role in the National Health System (SKN), especially the health care subsystem. Public Health Center is a health service facility that organizes public health efforts and first-level individual health efforts, with more priority to promotive and preventive efforts, to achieve the highest level of public health in its working area [1].

Accreditation of Community Health Centers is an acknowledgment of the results of the external assessment process, by the Accreditation Commissioner of Community Health Centers, whether in accordance with established accreditation standards. The purpose of the accreditation of this Community Health Center itself is to improve the quality of Community Health Center services [2].

In the evaluation of Community Health Center accreditation, there are three service groups assessed, namely in the form of a management administration group, a public health effort group (UKM), and also an individual health effort group. These three groups are the main points in the accreditation assessment of Community Health Centers where each group has established standards and assessment elements [3]. In order for the Community Health Center to perform its

Copyright @ 2020: This is an open-access article distributed under the terms of the Creative Commons Attribution license which permits unrestricted use, distribution, and reproduction in any medium for non commercial use (NonCommercial, or CC-BY-NC) provided the original author and source are credited. 
functions optimally, it is necessary to have a good organization of Community Health Center management that includes service performance, service processes, and resources used [4].

This needs to be done in the context of efforts to improve quality, risk management and patient safety at the Community Health Center and answer the community's need for safe and quality health services [5]. Policy implementation is basically influenced by several factors such as organizational structure, resources, communication, and also disposition or attitude. These four things affect the success of implementing a policy which in this case is the accreditation of Community Health Centers [6].

The Community Health Center is one of the health facilities that provide first level health services that have an important role in the National Health System (SKN), especially the health care subsystem. Community Health Center is a health service facility that organizes public health efforts and first-level individual health efforts, prioritizing promotive and preventive efforts, to achieve the highest level of public health in its working area [7].

In South Konawe there are 24 Community Health Centers and overall they have been accredited including the Other Community Health Centers, Motaha Community Health Centers, and Ranomeeto Community Health Centers which are community care centers and are mid-accredited but even though these three Community Health Centers are accredited to the Middle there are still many problems in applying the standards used as a reference for accreditation assessment.

Based on the observations and interviews of researchers found several obstacles in the implementation of accreditation policies in order to increase the work productivity of the Ranomeeto Community Health Center, the finding of Public Health Center officers who have multiple tasks due to limited human resources, the activities of the Public Health Center planning stages did not run according to the Central management cycle Public health.

This Accreditation Policy is an effort to ensure that quality improvement, increased work productivity and the application of risk management can be carried out on an ongoing basis [8], this study aims to review the implementation of the Accreditation Policy on work productivity at the Ranomeeto Community Health Center.

\section{METHODS}

\section{Research Design}

Descriptive qualitative research design using exploratory methods using in-depth interviews and literature studies to all research informants. This research was conducted at the Ranomeeto Community Health Center.

\section{Population and Sample}

The study population was all employees of the Community Health Center who worked at the Ranomeeto Community Health Center. To determine the number of sample sizes used purposive sampling method. The informant determination technique used is the inclusion and exclusion criteria so the number of informants in this study were 12 Public Health Center officers.

\section{Data Types and Sources}

This research uses primary data and secondary data. Primary data obtained from interviews and observations for qualitative data. Secondary data was obtained in writing through a review of important documents related to the workload analysis of community health workers.

\section{Data Analysis}

Analysis of the data used in this research is descriptive analysis. This analysis means that the data obtained from the study is presented as is then analyzed exploratively to get a picture of the facts that occur. There are two analytical models used, namely interactive model data analysis and descriptive data analysis.

\section{RESULTS}

\section{Resources}

Based on the results of interviews with informants related to How the availability of human resources in implementing the accreditation policy of the Public Health Center in improving work productivity as follows:

"if we are working on it, it is enough even though we are accustomed to other jobs but we try to maximize what we have to do on time and according to the target"

(AI, 39, Interview on 18 February 2020)

"I think, it has fulfilled the requirements and criteria although there are some educational backgrounds of our officers that are not appropriate but we are trying to maximize the performance in each of the snobs." 
(NM, 51, Interview on 18 February 2020)

From interviews with several informants related to local government support in the implementation of the accreditation of Community Health Centers so as to support work productivity at the Community Health Center as follows:

"the government, in this case, the South Konawe Regency health office, has greatly assisted us at the Community Health Center in implementing accreditation both mentally and financially."

(MYS, 49, Interview on 18 February 2020)

From the results of in-depth interviews with informants related to how the availability of the budget in supporting the accreditation policy as follows:

"related to the budget I think is enough, we set it in such a way as to the needs of accreditation and other matters"

(MYS, 49, Interview on 18 February 2020)

"it is not enough, there are programs that we are forced to outsmart how to avoid using more funds. So just paired up."

(HI, 41, Interview on 18 February 2020)

Based on interviews with informants related to facilities and infrastructure in the implementation of accreditation policies and can support increased work productivity at the Community Health Center as follows:

"Yes, due to budget constraints, the infrastructure is indeed limited, even though there have been some that are no longer functional and need to be updated, and then other facilities such as the cleanliness of the equipment, we still feel that it cannot be done routinely due to limitations that can calibrate. in this city."

(MYS, 49, Interview on 18 February 2020)

"if we discuss facilities and infrastructure there are still many things that need to be addressed, but this does not have a major effect on the productivity of officers carrying out their daily work"

(HI, 41, Interview on 18 February 2020)

Based on interviews with several informants related to the resource component, it can be concluded that the availability of human resources at Ranomeeto Community Health Center is sufficient in quantity with the existence of this accreditation. Public Health Centers can find out what HR will be needed in the future so that requests can be made to recruit HR what is needed, for local government support, in this case, the health department in South Konawe Regency has played an active role and assisted the Community Health Center in organizing accreditation both financially and providing assistance to each Community Health Center that carries out the accreditation process. As for the facilities and infrastructure at the Community Health Center, it is still inadequate so special attention is needed to follow up on the fulfillment of the facilities and infrastructure so as to increase the work productivity of the officers of the Public Health Center as a whole.

\section{Communication} follows:

Based on the results of interviews with informants related to the socialization of the accreditation policy as

"yes we always follow if there is a socialization related to accreditation, this is where we also update knowledge so that we know what components are needed at the time of accreditation"

(AI, 39, Interview on 18 February 2020)

From interviews with informants related to sharing with other teams / or other Community Health Centers in implementing accreditation policies in increasing work productivity as follows:

"often, we do communication to inform each other if there is something new that needs to be known, usually via $W A$, or sometimes we promise to meet with each other asking for solutions if there are problems we encounter."

(HI, 41, Interview on 18 February 2020)

"Sometimes we meet up after meeting at the health department there sometimes we discuss what are the things we can sample from friends who have accredited the Community Health Center, sometimes also in WA we communicate."

(AI, 39, Interview on 18 February 2020)

From the results of interviews related to the communication element that the officers of the Community Health Center in South Konawe Regency have participated in and held socialization related to accreditation policies, as well as the Public Health Center officers are also active in sharing good knowledge among fellow officers at the Community Health Center and even between the Community Health Centers. 


\section{DISCUSSION}

The success of policy implementation depends on the ability to utilize available resources. Humans are the most important resource in determining the success of a policy implementation. In addition to human resources, financial and time resources become important calculations in the successful implementation of policies [9].

Based on the results of research related to the availability of human resources in carrying out the Ranomeeto Community Health Center accreditation policy quantitatively the number of human resources has been sufficient in the implementation of accreditation and health services, this is evidenced by the results of interviews and document review owned by each Community Health Center. With the readiness of the Ranomeeto Community Health Center accreditation based on human resource management, it shows that the efforts to fulfill the staff of the Community Health Center have been carried out, regarding the calculation of clinical service personnel in the Ranomeeto Community Health Center more to the competency of each officer with a clear employment pattern in accordance with their respective competencies respectively.

As for those who do not have competencies assigned to the administration, while for the assessment and evaluation in ensuring work productivity a credential team and quality officer are formed. This is supported by the existence of documents about the pattern or distribution of types of personnel, performance appraisal documents, job description documents, SOPs, Decrees on credential teams and competency requirements for personnel providing health services.

To improve work productivity and service quality in the Community Health Center, the Community Health Center Management Team must be able to work well and professionally, under the coordination and supervision of the head of the Community Health Center who performs its leadership function properly and appropriately according to the situation and conditions [10].

The implementation of the policy will not succeed without the support of adequate and quality human resources. The quality of human resources is related to the skills, dedication, professionalism, and competence in their fields, while the strength relates to the amount of human resources whether it is sufficient to cover all target groups [11].

While the results of the interviews related to the support of local governments in the implementation of the accreditation of Community Health Centers that the local government, in this case, the South Konawe Regency health office fully supports the implementation of accreditation and program implementation, Community Health Center programs as for the form of support in the form of funding to support the implementation nets accreditation, facilitating meetings and outreach related to accreditation, supervision, and assistance at each Community Health Center, this is in accordance with the results of observations and study of documents conducted by researchers.

To support the process of implementing Accreditation in Community Health Centers, the full participation of relevant stakeholders such as the Regency / City Health Office, is very important in terms of the preparation stages of Community Health Center Accreditation from the initial stage to post-survey assistance. Some things that must be prepared by the Region in terms of the implementation of the Accreditation of Community Health Centers are: Facilities and infrastructure of Community Health Centers, Regency / City Budgeting, or Non-Physical DAK.

From the research results and observations and document review related to the availability of facilities and infrastructure in the accreditation policy implementation that there are still many facilities that are not yet available at the Ranomeeto Community Health Center, the completeness of facilities and infrastructure as a basis for performing standardized services is not yet fully available. The accreditation assessment will be based on the facilities available in performing services.

Where additional medical equipment is still needed, maintenance of medical devices for the three Community Health Centers, while for infrastructure at the Ranomeeto Community Health Center, several additional Public Health Center buildings, auxiliary Health Centers, Integrated Service Post, parking lots, other public facilities to support services are needed. health. This is due to the fact that the budget owned by the three Community Health Centers has not been sufficient to use the average budget used to pay for services, operations, and implementation of health programs.

Resources in policy implementation have an important role, because policy implementation will not be effective if the supporting resources are not available. The intended resources are human resources, budget resources, facilities, and infrastructure resources [12].

Communication is a very important part in achieving the goals and objectives of implementing a public policy. A policy will run well if effective communication occurs between program implementers and the groups 
that are the target of the policy. In addition, decision-makers and implementers in the field already know and understand what they are doing clearly and know why the policy was made [13].

From the results of observation, it is known that in the use of communication the policymakers, in this case, are the Accreditation Policy for Community Health Centers doing it straightforwardly and clearly so that it is easily understood by the communicants, namely health workers who work at the Ranomeeto Community Health Center. In addition, the organizational structure also determines the quality of the policy deliverers, where the officers delivering the existing Public Health Center Accreditation Policy must absolutely have a good disposition/attitude in conveying information in the form of a Public Health Center Accreditation Policy to health workers in the Center Ranomeeto Community Health so that the available organizational resources can be optimal. In communicating, communicators must be able to convey the message well to the communicants, that is they must be able to use the right channels so that efforts to deliver information about the Accreditation Policy for Public Health Centers can be about targets.

With the delivery of good information, the level of awareness of existing health workers will be about the importance of the Community Health Center Accreditation Policy which has an impact on the quality of Employee Productivity at the Ranomeeto Community Health Center. However, based on the results of the interview, there are still some health workers who still do not understand the meaning of the Community Health Center Accreditation Policy which must be implemented in each Community Health Center

Based on the results of in-depth interview research and document review on the socialization of the accreditation policy in supporting work productivity that the implementation of the socialization has been carried out both at the regency level and Community Health Centers and across sectors. The socialization was carried out in mentoring for the Ranomeeto Community Health Center, meetings, seminars which were usually conducted by the South Konawe regency health office.

The process of providing information through communication after paying attention to aspects of implementation also requires monitoring and evaluation aspects which are one unit, one of which is by measuring the impact of communication on the community (long, medium, and short term) [2].

From the results of research related to sharing with other teams / or other Community Health Centers in implementing the accreditation policy that active sharing is carried out both from team members, officers at other Community Health Centers. communication is done using the WhatsApp application, and at meetings in certain places.

The process of transferring news down within the organization or from one organization to another, and to other communicators, often experiences distortion, whether intentional or not. If different sources of communication provide unequal interpretations of a standard and purpose, or the same source of information provides conflicting interpretations, one-day policy implementers will find an event that is more difficult to implement a policy intensive [5].

Thus, the prospect of effective policy implementation is largely determined by accurate and consistent communication with policy implementers (accuracy and consistency). In addition, coordination is a powerful mechanism for policy implementation [1]. Policy analysis is carried out to create, critically assess, and communicate knowledge relevant to policy in one or more stages of the policymaking process [14]. The previous policy implementation process must have been thought of in formulating policies, because it is likely that failure in the implementation of policies mostly lies at the beginning of policy formulation [15].

\section{CONCLUSION}

Resources in policy implementation have an important role, because policy implementation will not be effective if the supporting resources are not available. the socialization of the accreditation policy in supporting work productivity that the implementation of the socialization has been carried out both at the regency level and the Community Health Center and across sectors. The socialization was carried out in assistance to the Ranomeeto Community Health Center. It is hoped that the Ranomeeto Community Health Center can maintain what has been achieved during the accreditation process, and carry out regular work productivity measurements.

\section{REFERENCES}

1. Lutfhan, R. H. A. T. K. (2013). Implementasi kebijakan subsidi pelayanan kesehatan dasar terhadap kualitas pelayanan puskesmas di Kota Singkawang. Jurnal Kebijakan Kesehatan Indonesia: JKKI, 2(4):180-188.

2. Rahman, A. (2019). Analisis Implementasi Kebijakan Akreditasi Pusat Kesehatan Masyarakat Dalam Rangka Meningkatkan Mutu Pelayanan Kesehatan Di Kabupaten Mamuju. Jurnal KESMAS. 
3. Utami, Y. T., Tamtomo, D., \& Sulaeman, E. S. (2017). Patient characteristics, financing type, accreditation status, and quality of health services at community health center, Surakarta. Journal of Health Policy and Management, 2(1), 79-90.

4. Putri, K. D., \& Adisti, Y. (2016). Analisis Pengaruh Tingkat Kesehatan, Tingkat Pendidikan, dan Upah Terhadap Produktivitas Tenaga Kerja di Indonesia. Universitas Airlangga. Jurnal Ilmu Ekonomi dan Pembangunan, 17(2):6777.

5. Misnaniarti, M., \& Destari, P. K. (2018). Aspek Penting Akreditasi Puskesmas dalam Mendukung Implementasi Jaminan Kesehatan Nasional. Jurnal Penelitian dan Pengembangan Pelayanan Kesehatan, 10-16.

6. Molyadi., \& Trisnantoro. (2018). Pelaksanaan Kebijakan Akreditasi Pusat Kesehatan Masyarakat di Kabupaten Kubu Raya. Jurnal Kebijakan Kesehatan Indonesia, 7(1):18-23.

7. Farzana, S., \& Arso. (2016). Analisis Kesiapan Akreditasi Dasar Pusat Kesehatan Masyarakat Mangkang Di Kota Semarang. Jurnal Kesehatan Masyarakat, 4(4):94-103.

8. Asmiati, S., \& Junaid. (2019). Analsis Kesiapan Akreditasi Berdasarkan Manajemen Sumber Daya Manusia Di Pusat Kesehatan Masyarakat Perumnas Kota Kendari. JIMKESMAS, 4(1):1-7.

9. Arshad., \& Malik. (2015). Quality of Human Capital and labor Productivity: a Case of Malaysia. International Journal of Economics, 23(1):37-55.

10. Maghfiroh, L. (2017). Analisis Kesiapan Pusat Kesehatan Masyarakat Demangan Kota Madiun Dalam Mengahdapi Akreditasi. Jurnal MKMI, 13(4):329-366.

11. Ulumiyah, N. H. (2018). Meningkatkan Mutu Pelayanan Kesehatan dengan Penerapan Upaya Keselamatan Pasien di Pusat Kesehatan Masyarakat. Jurnal Administrasi Kesehatan Indonesia UNAIR, 6(2):149-155.

12. Ensha, I. S. (2018). Pengaruh Implementasi Kebijakan Akreditasi Pusat Kesehatan Masyarakat terhadap Manajemen Pelayanan Kesehatan Masyarakat dalam Mewujudkan Produktivitas. Jurnal Publik, 12(1):12-23.

13. Indar. (2017). Etikolegal Dalam Pelayanan Kesehatan. Yogyakarta: Pustaka Pelajar.

14. Dumas, M. J., \& Anderson, G. (2014). Qualitative research as policy knowledge: Framing policy problems and transforming education from the ground up. Education Policy Analysis Archives/Archivos Analíticos de Políticas Educativas, 22, 1-21.

15. Gong, Y., \& Janssen, M. (2012). From policy implementation to business process management: Principles for creating flexibility and agility. Government Information Quarterly, 29, S61-S71. 